\title{
Policies, economic incentives and the adoption of modern irrigation technology in China
}

\author{
R. Cremades ${ }^{1,2}$, J. Wang ${ }^{3}$, and J. Morris ${ }^{4}$ \\ ${ }^{1}$ Research Unit Sustainability and Global Change, Departments of Geosciences and Economics, University of \\ Hamburg, Grindelberg 5, 20144 Hamburg, Germany \\ ${ }^{2}$ International Max Planck Research School on Earth System Modeling, Hamburg, Germany \\ ${ }^{3}$ Center for Chinese Agricultural Policy, Institute of Geographical Sciences and Natural Resources Research, \\ Chinese Academy of Sciences, No. Jia 11, Datun Rd., Anwai, Beijing 100101, China \\ ${ }^{4}$ Department of Environmental Science and Technology, Cranfield University, MK43 0AL, Bedfordshire, UK
}

Correspondence to: J. Wang (jxwang.ccap@igsnrr.ac.cn)

Received: 15 October 2014 - Published in Earth Syst. Dynam. Discuss.: 19 November 2014

Revised: 22 April 2015 - Accepted: 26 May 2015 - Published: 02 July 2015

\begin{abstract}
The challenges China faces in terms of water availability in the agricultural sector are exacerbated by the sector's low irrigation efficiency. To increase irrigation efficiency, promoting modern irrigation technology has been emphasized by policy makers in the country. The overall goal of this paper is to understand the effect of governmental support and economic incentives on the adoption of modern irrigation technology in China, with a focus on household-based irrigation technology and community-based irrigation technology. Based on a unique data set collected at household and village levels from seven provinces, the results indicated that householdbased irrigation technology has become noticeable in almost every Chinese village. In contrast, only about half of Chinese villages have adopted community-based irrigation technology. Despite the relatively high adoption level of household-based irrigation technology at the village level, its actual adoption in crop sown areas was not high, even lower for community-based irrigation technology. The econometric analysis results revealed that governmental support instruments like subsidies and extension services policies have played an important role in promoting the adoption of modern irrigation technology. Strikingly, the present irrigation pricing policy has played a significant but contradictory role in promoting the adoption of different types of modern irrigation technology. Irrigation pricing showed a positive impact on household-based irrigation technology, and a negative impact on community-based irrigation technology, possibly related to the substitution effect that is, the higher rate of adoption of household-based irrigation technology leads to lower incentives for investment in communitybased irrigation technology. The paper finally concludes and discusses some policy implications.
\end{abstract}

\section{Introduction}

Increasing industrial and urban demands for water are intensifying the pressure on agricultural water use in China. The water resources in the country are scarce and the annual water availability per capita is only approximately one-quarter of the world average (MWR, 2013). With increasing water demand from the industrial and domestic sectors, the share of water used in agriculture has declined from $97 \%$ in 1949 to $62 \%$ in 2013 (Wang et al., 2005; MWR, 2013). In addition, there is concern about future water deficits in irrigated agricultural production areas due to climate change; such deficits are projected to cause an estimated 7 to $14 \%$ drop in rice production that would threaten food security (Xiong et al., 2010). Furthermore, agricultural production in China is concentrated in areas that are increasingly prone to water shortages (FAO, 2011; Wu et al., 2011; Wu and Zhao, 2010). Some areas have also experienced environmental problems associated with water pollution and sea-water intrusion, thus limiting the availability of water for agricultural use (Mei and Dregne, 2001). 
The challenges China faces in terms of water availability in the agricultural sector are exacerbated by the sector's low irrigation efficiency (Cheng et al., 2009; Yang et al., 2003). In 2010, irrigation efficiency in China was estimated to be $48 \%$ on average; this figure is lower than that of some developed countries such as Israel (75\%) (Wang, et al., 2011). Such low irrigation efficiency is one of the major reasons of increasing water scarcity in China. An improvement on irrigation efficiency is necessary to maintain the use of existing irrigation capacity in the face of increasing demand for water from other sectors (Cheng and Hu, 2011; Zhang et al., 2005). Modern irrigation technology can make a substantial difference in efficiency and contribute to the successful adaptation of the agricultural sector to climate change in China (Belder, 2004; Erenstein et al., 2008; Zhao et al., 2010; Zou et al., 2013a, b). However, the adoption level of modern irrigation technology is low in China (Blanke et al., 2007).

The Chinese government stated that the promotion of modern irrigation technology is one of the priorities in its water conservancy reforms (CPC, 2010; USDA, 2011a). The rural and agriculture sections of China's twelfth Five-Year Plan, issued in March 2011, highlight the importance of efficiency and technological innovation (CPC, 2011a; USDA, 2011b). In addition, the Chinese government announced expenditures of over USD 600 billion on water conservation over 10 years starting in 2011 (CPC, 2011b), and an investment of USD 6.03 billion to specifically support the adoption of modern irrigation technology on 2.53 million ha (Xinhua, 2012). There is clearly a strong policy commitment to diffusing modern irrigation technology, but the likely impact of these interventions remains largely unknown.

\subsection{Scope}

For analytical convenience, Blanke et al. (2007) have divided irrigation technology into three groups: traditional, household-based and community-based. Traditional irrigation technology includes border irrigation, furrow irrigation and field leveling. These technologies are characterized by relatively low fixed costs and are divisible in the sense that one farm household can adopt the practice independently of its neighbors. Traditional irrigation technology is already widely adopted in China; it was used prior to the period of agricultural reform of the late 1970s and early 1980s. During the reform period, the adoption of traditional technologies grew slowly, in part due to the relatively high prevailing adoption level. When policy makers and scholars in China refer to the adoption of modern irrigation technology, they mainly emphasize the adoption of household-based and community-based irrigation technologies. Unlike traditional technology, these two categories of technology have been adopted mainly since the 1980s. Given this observation, we refer to them as modern irrigation technologies and focus on their adoption in our paper.
As modern irrigation technology, household-based and community-based irrigation technologies have different characteristics. Household-based irrigation technology includes intermittent irrigation, surface pipes, plastic-film mulching, reduced or no tillage, retaining stubble, incorporation of crop residue and use of drought-resistant crop varieties. Household-based irrigation technology can be adopted separately by each household and have low fixed costs. Community-based irrigation technology includes sprinklers, drip irrigation, underground pipes and lined canals. These technologies are not typically adopted by single households; they normally require collective organization by farmer groups or village committees. In contrast to traditional and household-based irrigation technology, community-based irrigation technology has higher fixed costs. The adoption of sprinklers, drip irrigation and underground pipes is more recent (1990s) than the adoption of household-based technology, but lined canals were used earlier (Blanke et al., 2007).

The existing literature tells us that governmental support is an important factor in farmers' decisions whether to adopt modern irrigation technology. Policies promoting adoption of modern irrigation technology often aim to overcome farmers' economic and technical constraints. To overcome economic constraints, direct provision of subsidies has proven to be an important policy measure in increasing the adoption level of modern irrigation technology, especially when the prevailing adoption levels are low (Feder and Umali, 1993; Tiwari and Dinar, 2000). Liu et al. (2008) found a significant positive relationship between subsidies and adoption of some types of irrigation technology in rural China. In terms of technical constraints, providing knowledge and technical advice through extension service activities are effective ways to increase the adoption level of modern irrigation technology (Dong, 2008; Feder and Umali, 1993; Ommani et al., 2009).

In addition to governmental support, setting rational economic incentives for farmers is another important factor that influences farmers' technology adoption behavior. International experience indicates that water price is a significant determinant of adoption of modern irrigation technology in the agricultural sector (Dinar and Yaron, 1992; Negri and Brooks, 1990; Zilberman and Caswell, 1985). Although Blanke et al. (2007) do not conduct a quantitative analysis, they argue that reforming water pricing in China will promote the adoption of modern irrigation technology. However, most research concurs that in China's agricultural sector, the "price" of water in terms of actual water charges is low, which constrains its potential role in promoting the use of modern irrigation technology (Finlayson et al., 2008; Huang et al., 2010).

\subsection{Goal and objectives}

To design more effective policies to foster the adoption of modern irrigation technology in China, it is essential to an- 
swer the following questions: what are the current levels of extent and intensity of adoption of modern irrigation technology in rural China? Have interventions such as subsidy and extension policies played a significant role in promoting the adoption of modern irrigation technology? Could economic incentives established through a water pricing policy play an important role in increasing the adoption level of modern irrigation technology? Despite a relatively rich international literature quantitatively analyzing the determinants of adoption of modern irrigation technology (Webb et al., 2005; Zilberman and Caswell, 1985; Dinar and Yaron, 1992), such studies focused on China are very few. We only found a few quantitative analyses that explore the factors influencing the adoption of modern irrigation technology in China, such as those by Liu et al. (2008) and Zhou et al. (2008). More importantly, no study has assessed the effectiveness of economic incentives in promoting the adoption of modern irrigation technology in rural China.

The overall goal of this paper is to understand the effect of governmental support and economic incentives on the adoption of modern irrigation technology in China. With this goal in mind, the following objectives have been specified. First, we examine the extent of adoption of modern irrigation technology at households and village levels. Second, we quantitatively identify the policy drivers that have been most important in promoting the adoption of modern irrigation technology. Third, we explore the influence of economic incentives (in terms of charges for irrigation water) on the adoption of modern irrigation technology.

The paper is organized as follows. The next section explains materials and methods, including sampling procedures, survey design and data collection, indicators for measuring the adoption of irrigation technology, and specification of econometric model. Based on descriptive statistical analyses and econometric model estimation, Sect. 3 presents analyses and results of the adoption status of modern irrigation technology (household-based and community-based technologies) and major factors influencing the adoption. Section 4 discusses the results and concludes.

\section{Materials and methods}

\subsection{Sampling procedures}

The data used in this study are collected from one large-scale household survey conducted in seven provinces in China, which allow for regional variation in geophysical conditions and levels of socioeconomic development. These seven provinces include Beijing and Hebei in the Haihe River basin (RB), Jilin in the Songliao RB, Anhui in the Huaihe RB, Sichuan in the Yangtze RB, Yunnan in the southwest RB and Zhejiang in the southeast RB (Fig. 1). When selecting provinces for the field survey, we accounted for the differences in climate and water resources between northern and southern regions; in addition, the pattern of diverse eco-

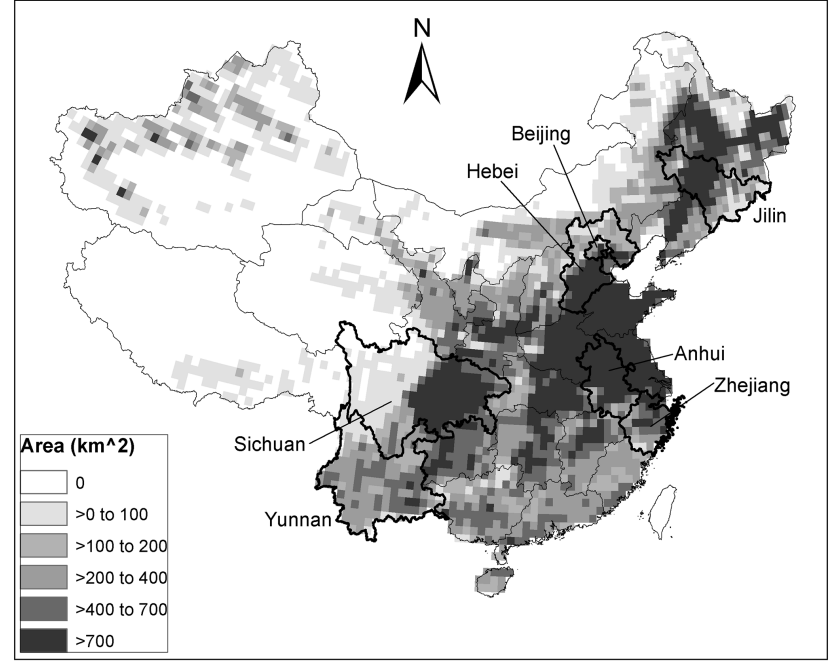

Figure 1. Map of China illustrating the surveyed provinces in bold over pixels showing density of square kilometers of total sown area of rice, wheat, maize and soy in 2000. Source: authors, using data from Qiu et al. (2003).

nomic development has been considered. For example, the survey samples cover three river basins (Songliao, Haihe and Huaihe RBs) characterized by less precipitation, while the other three river basins (the Yangtze, southwest and southeast RBs) have more abundant precipitation and water resources. These regions also represent high (Zhejiang Province), middle (Jilin and Hebei Provinces) and low (Anhui, Sichuan and Yunnan Provinces) levels of economic development (NBSC, 2010).

Stratified random sampling was used in each province to select study areas. First, we divided all counties in each province into three quantiles by the per capita annual net income of rural residents in 2009. In each quantile, we randomly selected one county to be surveyed. After the counties were chosen, we randomly selected two townships in each county and three villages in each township for field surveys. In each village, we randomly selected 10 households with which to conduct the field survey. Therefore, the survey sample included a total of 20 counties, 40 townships, 123 villages and 1269 households. Because farmers in rainfed areas do not need to pay an irrigation fee - one of the key variables that we are interested in - in the analysis, we only focus on those farmers who reported that they use irrigation for crop production. The final samples used in the analysis include 993 households in 118 villages in 20 counties.

\subsection{Survey design and data collection}

In each village, we conducted two surveys, the household and the village surveys. While the household- and village-level surveys cover a wide range of issues, our analysis only used data relevant to this study. From the household-level surveys, 
Table 1. Descriptive statistics for major variables included in the study.

\begin{tabular}{|c|c|c|}
\hline & Mean & Std. dev. \\
\hline \multicolumn{3}{|l|}{ Village-level variables } \\
\hline Financial subsidies $(1=$ Yes; $0=$ No $)$ & 0.15 & 0.36 \\
\hline Extension service $(1=$ Yes; $0=$ No $)$ & 0.64 & 0.48 \\
\hline Proportion of years without reliable water supply & 0.05 & 0.21 \\
\hline Exclusive use of groundwater $(1=$ Yes; $0=$ No $)$ & 0.14 & 0.35 \\
\hline Proportion of irrigated area & 0.71 & 0.28 \\
\hline Distance to township government $(\mathrm{km})$ & 5.97 & 5.24 \\
\hline \multicolumn{3}{|l|}{ County-level variable } \\
\hline Precipitation (mm) & 1078 & 336 \\
\hline \multicolumn{3}{|l|}{ Household-level variables } \\
\hline Adoption of community-based irrigation technology $(1=$ Yes; $0=\mathrm{No})$ & 0.49 & 0.50 \\
\hline Adoption of household-based irrigation technology $(1=$ Yes; $0=$ No $)$ & 0.11 & 0.31 \\
\hline Ratio of irrigation fee to net cropping income (ratio) & 0.01 & 0.03 \\
\hline Amount of irrigation fee (Yuan per ha) & 26.03 & 40.61 \\
\hline Proportion of household area adopting community-based irrigation technology & 0.55 & 0.40 \\
\hline Proportion of household area adopting household-based irrigation technology & 0.16 & 0.35 \\
\hline Gender of household head $(1=$ Male; $0=$ Female $)$ & 0.99 & 0.11 \\
\hline Age of household head (Years) & 52.67 & 10.53 \\
\hline Education of household head (Years) & 6.80 & 2.97 \\
\hline Proportion of off-farm labor & 0.27 & 0.28 \\
\hline Household assets (Yuan 10000 ) & 13.50 & 30.19 \\
\hline \multicolumn{3}{|l|}{ Plot-level variables } \\
\hline Crop sown area $(\mathrm{Ha})$ & 138.11 & 564.85 \\
\hline Loam soil $(1=$ Yes; $0=$ No $)$ & 0.24 & 0.43 \\
\hline Clay soil $(1=$ Yes; $0=$ No $)$ & 0.43 & 0.50 \\
\hline Plain terrain $(1=$ Yes; $0=\mathrm{No})$ & 0.67 & 0.47 \\
\hline High-quality plot $(1=$ Yes; $0=$ No $)$ & 0.19 & 0.39 \\
\hline Medium-quality plot $(1=$ Yes; $0=\mathrm{No})$ & 0.67 & 0.47 \\
\hline Saline plot $(1=$ Yes; $0=$ No $)$ & 0.03 & 0.18 \\
\hline Distance from house to plots $(\mathrm{km})$ & 0.74 & 0.75 \\
\hline
\end{tabular}

we used the following data: (i) whether any kind of modern irrigation technology was adopted in each plot, and which areas adopt modern irrigation technology; (ii) annual irrigation fee paid for each plot; (iii) the household characteristics, including the gender, age, and education of household heads, hours of total labor and off-farm labor, household assets, and production inputs and outputs for each plot that can be used for calculating net cropping income; and (iv) the plot characteristics, including crop sown area, soil type, soil quality, saline nature, topography and the distance from the households to the plot.

From the village-level surveys, we used the following data: (i) whether the households in the village adopted any kind of modern irrigation technology in their plots; (ii) whether the village obtained financial subsidies for the adoption of modern irrigation technology; (iii) whether the village obtained extension services on adopting modern irrigation technology, such as extension experts coming to the villages to guide farmers, or the village being an experimental site for modern irrigation technology; (iv) the proportion of irrigated area; (v) the distance to township government; (vi) whether groundwater is being used for irrigation, and groundwater reliability in the past 5 years. Finally, we obtained the annual precipitation data for each county from the Chinese National Meteorological Information Center. Table 1 provides the descriptive statistics for the data used in the study.

\subsection{Indicators for measuring the adoption of irrigation technology}

In the following discussion, we examine two dimensions of the adoption of modern irrigation technology: the extent of adoption, and its intensity. The extent of adoption measures how spatially pervasive modern irrigation technology has become. To measure the extent of adoption, we apply the information collected at the village, household and plot levels. At 
the village level, we intend to reveal the percentage of villages that are adopting modern irrigation technology. By our definition, if even a single household in the village adopts modern irrigation technology, the village is considered to have adopted the technology. Similarly, even if a household uses modern irrigation technology on only one plot, the household is considered as having adopted modern irrigation technology. The extent of adoption at the household level is measured by the percentage of households adopting modern irrigation technology. The extent of adoption at the plot level is measured by the percentage of plots adopting modern irrigation technology. To measure adoption intensity, we use the percentage of crop sown areas that adopt modern irrigation technology.

\subsection{Specification of econometric methods for analyzing major factors influencing the adoption of modern irrigation technology}

To identify the influence of policies, economic incentives and other factors on the adoption of modern irrigation technology (household- and community-based irrigation technology), the following econometric methods have been specified.

In Eq. (1), $A_{i j k}$ represents the adoption of modern irrigation technology (household-based or community-based technology) for the $i$ th plot of household $j$ in village $k . A_{i j k}$ is a dummy variable that is 1 when the plot adopts irrigation technology and 0 otherwise. Among the explanatory variables, $S_{i j k}, E_{i j k}$ and IFCI $\mathrm{I}_{i j k}$ are the variables of interest. $S_{i j k}$ is a qualitative dummy variable that represents the availability of subsidies to households for investing in modern irrigation technology; it is 1 when the subsidy is available and 0 otherwise. Similarly, $E_{i j k}$ is a dummy variable capturing the availability of extension service activities that is 1 when the activities are available and 0 otherwise. IFCI $_{i j k}$ is the ratio of the irrigation fee to net cropping income of the household; this variable expresses the importance of an annual per-area irrigation fee relative to the household's economic standing.

$C_{i j k}$ is a set of control variables included to reduce omitted variable bias. It includes variables related to village, household and plot characteristics. Village variables include the proportion of irrigated area, the distance to the township government $(\mathrm{km})$, the proportion of years without reliable groundwater supply in the last 5 years, a dummy variable reflecting the exclusive use of groundwater ( 1 is yes, 0 is no) and precipitation at the county level (mm). Household variables include the proportion of off-farm labors in the household, household assets (10 000 Yuan), education (years), gender (1 is male, 2, female) and age (years) of the head of household. Variables related to a particular plot include the distance from house to the plot $(\mathrm{km})$ and six dummy variables ( 1 is yes, 0 no) regarding various characteristics of the plot: loam soil, clay soil, plain terrain, high-quality, mediumquality and saline soil. $\beta, \gamma, \delta$ and $\lambda$ are the parameters to be estimated. The error term, $\varepsilon_{i j k}$, is assumed to be uncorrelated with the independent variables.

In Eq. (2), $I_{j k}$ represents the intensity of adoption of modern irrigation technology for the $j$ th household in village $k$, measuring the proportion of crop sown areas adopting modern irrigation technology. Similar to Eq. (1), Eq. (2) also includes explanatory variables such as the availability of subsidies, the availability of extension service and IFCI. In Eq. (2), the variables related to village and household characteristics are the same as those in Eq. (1). However, in Eq. (2) the variables related to the characteristics of the plots of the household are not the same. Instead, they are the average distance from the house to the various plots of the households $(\mathrm{km})$, and six variables reflecting the proportion of the household's plots that exhibit a given characteristic. These six variables include the proportion of loam soil plots in the household (ratio), and five analogous variables describing the proportion of plots with the following characteristics: plain terrain, clay soil, high-quality, medium-quality and saline soil.

In Eq. (1), since the dependent variable is a dummy variable, we used a Logit model to estimate it (Train, 1993). For Eq. (2), considering some values of the dependent variable are zero, since not all plots adopted the modern irrigation technology, in order to reduce the estimation biases, the Tobit model is used (Feder and Umali, 1993).

\section{Analyses and results}

\subsection{Adoption of modern irrigation technology}

Our data indicate that almost all villages in China adopted household-based modern irrigation technology. For example, $99 \%$ of sampled villages adopted household-based irrigation technology in 2010 (Table 2, column 1). It implies that household-based irrigation technology has become a pervasive practice for farmers to increase irrigation efficiency of agricultural activities. However, only $47 \%$ of villages adopted community-based irrigation technology (column 2).

Consistent with the village-scale data, at household and plot scales, the levels of adoption of household-based irrigation technology are much higher than the levels of community-based irrigation technology. For example, $73 \%$ of all households reported that they adopted some types of household-based irrigation technology in 2010 (Table 2, column 1). On average, household-based irrigation technology was adopted in $54 \%$ of plots. Turning to community-based irrigation technology, we find that only $17 \%$ (Table 2 , column 2) of households adopted this category of irrigation technology and the percentage of plots adopting the technology was only $14 \%$ (column 2 ).

Despite the relatively high adoption level of householdbased irrigation technology at the village and household level, its actual adoption on crop sown areas is not high: roughly one-third of crop sown areas are utilizing this technology. The level of intensity of adoption for community- 
Table 2. The adoption extent and intensity of modern irrigation technology in China, 2010.

\begin{tabular}{lcc}
\hline & $\begin{array}{c}\text { Household-based } \\
\text { technology }\end{array}$ & $\begin{array}{c}\text { Community-based } \\
\text { technology }\end{array}$ \\
\hline Adoption extent & \\
\hline Percentage of villages (\%) & 99 & 47 \\
Percentage of households (\%) & 73 & 17 \\
Percentage of plots (\%) & 54 & 14 \\
\hline \multicolumn{2}{c}{ Adoption intensity } \\
\hline Percentage of crop sown areas (\%) & 32 & 4 \\
\hline Data source: authors' survey. & &
\end{tabular}

Table 3. Relationship between governmental support and adoption of modern irrigation technology in China, 2010.

\begin{tabular}{|c|c|c|c|c|}
\hline & \multicolumn{2}{|c|}{$\begin{array}{c}\text { Adoption extent: share of plots } \\
\text { adopting }(\%)\end{array}$} & \multicolumn{2}{|c|}{$\begin{array}{l}\text { Adoption intensity: share of crop- } \\
\text { sown areas adopting }(\%)\end{array}$} \\
\hline & $\begin{array}{l}\text { Household- } \\
\text { based } \\
\text { technology }\end{array}$ & $\begin{array}{l}\text { Community- } \\
\text { based } \\
\text { technology }\end{array}$ & $\begin{array}{l}\text { Household- } \\
\text { based } \\
\text { technology }\end{array}$ & $\begin{array}{l}\text { Community- } \\
\text { based } \\
\text { technology }\end{array}$ \\
\hline \multicolumn{5}{|c|}{ Financial subsidy } \\
\hline Available & 73 & 29 & 77 & 24 \\
\hline Not available & 50 & 11 & 45 & 6 \\
\hline \multicolumn{5}{|c|}{ Extension service } \\
\hline Available & 61 & 18 & 50 & 8 \\
\hline Not available & 41 & 8 & 42 & 8 \\
\hline
\end{tabular}

Data source: authors' survey.

based irrigation technology is even lower. Our data reveals that in the full sample, community-based irrigation technology is used on only $4 \%$ of crop sown areas (Table 2 , row 4 ). Our data are consistent with the findings of other researchers (such as Blanke et al., 2007; Liu et al., 2008) who also found that the intensity of adoption of modern irrigation technology is very limited.

\subsection{Governmental support, economic incentives and the adoption of modern irrigation technology in China}

Consistent with other studies (Dinar and Yaron, 1992; Ommani et al., 2009), descriptive statistical analyses show a possible positive relationship between the adoption of modern irrigation technology and policies encouraging it. In our analysis, we use two variables to represent governmental support: a subsidy for investing in irrigation technology and extension services that assist farmers in becoming familiar with the application of irrigation technology. Based on our field survey, we found that $15 \%$ of households accessed the subsidy policy. More importantly, when subsidies are available to farmers, they are more likely to adopt both household-based and community-based irrigation technology. For example, if the subsidy was available, $73 \%$ of plots adopted householdbased irrigation technology; the adoption level was only $50 \%$ if the subsidy was not available (Table 3, column 1). Similarly, if farmers can obtain the subsidy when they invest in modern irrigation technology, the adoption level of plots for community-based irrigation technology (29\%) was also considerably higher than without the subsidy $(11 \%)$ (Table 3 , column 2).

When the subsidy policy is available, the percentage of crop sown areas to which modern irrigation technology was applied was higher. Specifically, in households where the subsidy was available, the average intensity of adoption of household-based irrigation technology was $77 \%$ (Table 3, column 3), while the average intensity of adoption was lower $(45 \%)$ in those households where the subsidy policy was not available. In the case of community-based irrigation technology, the availability of subsidies makes also a difference, although smaller. If the subsidy was available, the average intensity of adoption of community-based irrigation technology was $24 \%$ (Table 3, column 4), while the figure was much lower $(6 \%)$ if the subsidy policy was not available. This smaller difference most likely arises because community- 
Table 4. Relationship between economic incentives and adoption of modern irrigation technology in China, 2010.

\begin{tabular}{|c|c|c|c|c|}
\hline & \multicolumn{2}{|c|}{$\begin{array}{c}\text { Adoption extent: share of plots } \\
\text { adopting }(\%)\end{array}$} & \multicolumn{2}{|c|}{$\begin{array}{l}\text { Adoption intensity: share of } \\
\text { crop sown areas adopting }(\%)\end{array}$} \\
\hline & $\begin{array}{l}\text { Household- } \\
\text { based } \\
\text { technology }\end{array}$ & $\begin{array}{l}\text { Community- } \\
\text { based } \\
\text { technology }\end{array}$ & $\begin{array}{l}\text { Household- } \\
\text { based } \\
\text { technology }\end{array}$ & $\begin{array}{l}\text { Community- } \\
\text { based } \\
\text { technology }\end{array}$ \\
\hline \multicolumn{5}{|c|}{$\begin{array}{l}\text { Ratio of irrigation fee to } \\
\text { net cropping income }\end{array}$} \\
\hline 0 & 47 & 11 & 45 & 7 \\
\hline$>0$ & 59 & 16 & 49 & 8 \\
\hline
\end{tabular}

Data source: authors' survey.

based irrigation technology has higher fixed costs; thus, the subsidy policy plays a fundamental role in adoption.

Our data also show that when extension services were available, the likelihood that farmers will adopt modern irrigation technology was higher. According to our field survey, $64 \%$ of households had access to support activities from extension services. When extension services were available, $61 \%$ of plots adopted household-based irrigation technology, while the level of adoption was only $41 \%$ if these services were not available (Table 3 , column 1 , last two values). Similarly, the availability of extension services was associated with a higher adoption level of community-based irrigation technology (18\% versus $8 \%$, column 2 ). Likewise, the provision of extension services also appears to increase the adoption intensity of modern irrigation technology. If the extension service activities were implemented, the adoption intensity of household-based irrigation technology increased from 42 to $50 \%$ (column 3), but the adoption intensity of community-based irrigation technology remained at $8 \%$ (column 4). Although the availability of extension services seems to have an impact on the intensity of adoption of household-based irrigation technology, the differences of values in Table 3 imply that the availability of subsidies may have a larger impact on the adoption of modern irrigation technology.

Charges for irrigation water can provide an economic incentive to conserve water through the adoption of modern irrigation technology (Tiwari and Dinar, 2000). Among the surveyed households that irrigate, almost all farmers that exclusively use groundwater paid for water, whereas only about half of the exclusive surface water users paid for water. Surface water users often pay less for water because they usually have optional sources from which to obtain water, some of which are free, such as using water directly from rivers, water cellars, ponds, small streams or springs. Payment for irrigation water is reflected here by the proportion irrigation fee to net cropping income of household (IFCI).

Our descriptive statistical analyses suggest the existence of a positive relationship between payment for water (IFCI) and the adoption of modern irrigation technology. When there was a water fee, farmers exhibited a positive increase difference in the extent of adoption of household-based and community-based irrigation technology. For example, Table 4 (column 1) displays that in plots from households with values of IFCI larger than 0 , the adoption extent of household-based irrigation technology was $12 \%$ higher than among those plots without payment. A lower increase in the adoption level $(5 \%)$ was evident in the extent of adoption of community-based irrigation technology (column 2), although less perceivable increases are apparent in the adoption intensity of modern irrigation technologies (columns 3 and 4).

\subsection{Estimation results of econometric models}

The estimated results of the four models show that they all perform well (Tables 5 and 6). The models passed the Chisquare test, and the pseudo $R^{2}$ values of the four models range from 0.072 to 0.288 . These values are sufficiently high enough for regression analyses based on large-scale crosssectional data. Moreover, many village, household and plot control variables have signs that agree with our expectations and are statistically significant. For instance, in the four models, the sign of the coefficient of exclusive use of groundwater is positive and statistically significant (Tables 5 and 6). This outcome implies that after keeping all other factors constant, farmers using groundwater exclusively are more likely to adopt modern irrigation technology. This result is in agreement with findings of other researchers (Yang et al., 2003; Caswell et al., 1990). The results also indicate that farmers with a higher education level are more likely to adopt community-based irrigation technology with more extent and intensity, as expected. In the same way, adoption is positive and significantly related to plain terrain and plots with saline conditions. This relationship implies that modern irrigation technology is more likely to be adopted in plots with no slope conditions and can minimize the effects of soil salinity, which is consistent with previous findings (Castilla, 1999).

More importantly, the results show that when the subsidy policy is available to farmers, the farmers adopt mod- 
Table 5. Estimates of determinants of the adoption decision of modern irrigation technology in China (Logit model).

\begin{tabular}{|c|c|c|}
\hline & \multicolumn{2}{|c|}{ Whether the plot adopts $(1=$ Yes; $0=$ No $)$} \\
\hline & $\begin{array}{l}\text { Household-based } \\
\text { irrigation } \\
\text { technology }\end{array}$ & $\begin{array}{l}\text { Community-based } \\
\text { irrigation } \\
\text { technology }\end{array}$ \\
\hline \multicolumn{3}{|c|}{ Governmental support } \\
\hline Financial subsidies $(1=$ Yes; $0=$ No $)$ & $\begin{array}{l}0.117^{* * *} \\
(4.71)\end{array}$ & $\begin{array}{l}0.020^{* *} \\
(2.11)\end{array}$ \\
\hline \multicolumn{3}{|c|}{ Extension service $(1=$ Yes; $0=$ No $)$} \\
\hline $0.106^{* * *}$ & $\begin{array}{l}0.008 \\
(5.43)\end{array}$ & $(0.98)$ \\
\hline \multicolumn{3}{|c|}{ Economic incentives } \\
\hline Ratio of irrigation fee to net cropping income & $\begin{array}{l}1.346^{* * *} \\
(3.77)\end{array}$ & $\begin{array}{l}-0.822^{* * *} \\
(3.74)\end{array}$ \\
\hline \multicolumn{3}{|c|}{ Village characteristics } \\
\hline Proportion of irrigated area & $\begin{array}{l}0.276^{* * *} \\
(7.79)\end{array}$ & $\begin{array}{l}0.093^{* * *} \\
(6.19)\end{array}$ \\
\hline Distance to township government $(\mathrm{km})$ & $\begin{array}{l}0.001 \\
(0.40)\end{array}$ & $\begin{array}{l}-0.000 \\
(0.59)\end{array}$ \\
\hline Proportion of years without reliable water supply & $\begin{array}{l}0.015 \\
(0.31)\end{array}$ & $\begin{array}{l}0.003 \\
(0.23)\end{array}$ \\
\hline Exclusive use of groundwater $(1=$ Yes; $0=$ No $)$ & $\begin{array}{l}0.100^{* * *} \\
(2.94)\end{array}$ & $\begin{array}{l}0.080^{* * *} \\
(6.68)\end{array}$ \\
\hline Annual total precipitation (mm) & $\begin{array}{l}-0.0001^{* *} \\
(2.01)\end{array}$ & $\begin{array}{l}-0.0001^{* * *} \\
(5.05)\end{array}$ \\
\hline
\end{tabular}

\begin{tabular}{lll}
\hline \multicolumn{3}{c}{ Household characteristics } \\
\hline Gender of household head (1= Male; 0= Female) & $-0.141^{*}$ & -0.018 \\
& $(1.84)$ & $(0.71)$ \\
Age of household head (years) & $-0.002^{* *}$ & -0.000 \\
& $(2.18)$ & $(0.01)$ \\
Education of household head (years) & 0.005 & $0.005^{* * *}$ \\
Proportion of off-farm labor & $(1.54)$ & $(4.09)$ \\
& -0.017 & $0.057^{* * *}$ \\
Household assets (Yuan 10000) & $(0.56)$ & $(5.25)$ \\
& $0.001^{* * *}$ & $0.0001^{* * *}$ \\
& $(2.65)$ & $(2.78)$ \\
\hline
\end{tabular}

\begin{tabular}{lll}
\hline & Plot characteristics & \\
\hline Loam soil $(1=$ Yes; $0=$ No $)$ & $-0.046^{* *}$ & 0.010 \\
& $(1.98)$ & $(1.12)$ \\
Clay soil $(1=$ Yes; $0=$ No $)$ & $-0.056^{* * *}$ & $-0.015^{*}$ \\
Plain terrain $(1=$ Yes; $0=$ No $)$ & $(2.86)$ & $(1.96)$ \\
& 0.002 & $0.040^{* * *}$ \\
High-quality plot $(1=$ Yes; $0=$ No) & $(0.12)$ & $(4.21)$ \\
& 0.044 & $0.026^{* *}$ \\
Medium-quality plot $(1=$ Yes; $0=$ No $)$ & $(1.48)$ & $(2.25)$ \\
& $0.059^{* *}$ & $0.020^{* *}$ \\
Saline plot $(1=$ Yes $0=$ No) & $(2.44)$ & $(2.02)$ \\
& $0.092^{* *}$ & $0.050^{* * *}$ \\
Distance from house to plots $(\mathrm{km})$ & $(2.00)$ & $(4.06)$ \\
& $0.039^{* * *}$ & $-0.011^{* *}$ \\
\hline Observations & $(3.42)$ & $(2.01)$ \\
Prob $>\chi^{2}$ & 4172 & 4172 \\
Pseudo $R^{2}$ & 0 & 0 \\
\hline
\end{tabular}

Notes: estimates are marginal effects. Absolute value of $z$ statistics in parentheses. ${ }^{* * *} p<0.01,{ }^{* *} p<0.05,{ }^{*} p<0.1$. Data source: authors' survey. 
Table 6. Estimates of determinants of the adoption intensity of modern irrigation technology in China (Tobit model).

\begin{tabular}{|c|c|c|}
\hline & \multicolumn{2}{|c|}{ Proportion of crop sown areas adopting } \\
\hline & $\begin{array}{l}\text { Household-based } \\
\text { irrigation } \\
\text { technology }\end{array}$ & $\begin{array}{l}\text { Community-based } \\
\text { irrigation } \\
\text { technology }\end{array}$ \\
\hline \multicolumn{3}{|c|}{ Governmental support } \\
\hline Financial subsidies $(1=$ Yes; $0=$ No $)$ & $\begin{array}{l}0.106^{* * *} \\
(2.69)\end{array}$ & $\begin{array}{l}0.130 \\
(1.47)\end{array}$ \\
\hline Extension service $(1=$ Yes; $0=$ No $)$ & $\begin{array}{l}0.102^{* * *} \\
(3.12)\end{array}$ & $\begin{array}{l}0.043 \\
(0.49)\end{array}$ \\
\hline \multicolumn{3}{|c|}{ Economic incentives } \\
\hline Ratio of irrigation fee to net cropping income & $\begin{array}{l}-0.003 \\
(0.01)\end{array}$ & $\begin{array}{l}-1.223 \\
(0.94)\end{array}$ \\
\hline \multicolumn{3}{|c|}{ Village characteristics } \\
\hline Proportion of irrigated area & $\begin{array}{l}0.247^{* * *} \\
(4.33)\end{array}$ & $\begin{array}{l}0.867^{* * *} \\
(5.18)\end{array}$ \\
\hline Distance to township government $(\mathrm{km})$ & $\begin{array}{l}-0.002 \\
(0.67)\end{array}$ & $\begin{array}{l}0.009 \\
(1.17)\end{array}$ \\
\hline Proportion of years without reliable water supply & $\begin{array}{l}0.028 \\
(0.47)\end{array}$ & $\begin{array}{l}0.056 \\
(0.40)\end{array}$ \\
\hline Exclusive use of groundwater $(1=$ Yes; $0=$ No $)$ & $\begin{array}{l}0.175^{* * *} \\
(3.29)\end{array}$ & $\begin{array}{l}0.411^{* * *} \\
(3.67)\end{array}$ \\
\hline Annual total precipitation (mm) & $\begin{array}{l}-0.0001^{* * *} \\
(5.52)\end{array}$ & $\begin{array}{l}-0.001^{* * *} \\
(7.32)\end{array}$ \\
\hline \multicolumn{3}{|c|}{ Household characteristics } \\
\hline Gender of household head $(1=$ Male; $0=$ Female $)$ & $\begin{array}{l}0.036 \\
(0.41)\end{array}$ & $\begin{array}{l}0.080 \\
(0.41)\end{array}$ \\
\hline Age of household head (years) & $\begin{array}{l}-0.001 \\
(0.72)\end{array}$ & $\begin{array}{l}0.002 \\
(0.52)\end{array}$ \\
\hline Education of household head (years) & $\begin{array}{l}0.005 \\
(0.88)\end{array}$ & $\begin{array}{l}0.035^{* *} \\
(2.40)\end{array}$ \\
\hline Proportion of off-farm labor & $\begin{array}{l}-0.021 \\
(0.40)\end{array}$ & $\begin{array}{l}0.199 \\
(1.48)\end{array}$ \\
\hline Household assets (Yuan 10000 ) & $\begin{array}{l}0.000 \\
(0.56)\end{array}$ & $\begin{array}{l}0.002^{* *} \\
(2.40)\end{array}$ \\
\hline \multicolumn{3}{|c|}{ Plot characteristics } \\
\hline Proportion of loam soil plots & $\begin{array}{l}0.060 \\
(1.33)\end{array}$ & $\begin{array}{l}0.317^{* * *} \\
(2.68)\end{array}$ \\
\hline Proportion of clay soil plots & $\begin{array}{l}0.103^{* * *} \\
(2.86)\end{array}$ & $\begin{array}{l}0.085 \\
(0.90)\end{array}$ \\
\hline Proportion of plain terrain plots & $\begin{array}{l}0.112^{* * *} \\
(2.93)\end{array}$ & $\begin{array}{l}0.254^{* *} \\
(2.31)\end{array}$ \\
\hline Proportion of high-quality plots & $\begin{array}{l}0.004 \\
(0.07)\end{array}$ & $\begin{array}{l}0.226 \\
(1.45)\end{array}$ \\
\hline Proportion of medium-quality plots & $\begin{array}{l}-0.013 \\
(0.26)\end{array}$ & $\begin{array}{l}0.210 \\
(1.57)\end{array}$ \\
\hline Proportion of saline plots & $\begin{array}{l}0.074 \\
(0.97)\end{array}$ & $\begin{array}{l}0.305^{*} \\
(1.89)\end{array}$ \\
\hline Distance from house to plots $(\mathrm{km})$ & $\begin{array}{l}-0.018 \\
(0.89)\end{array}$ & $\begin{array}{l}-0.036 \\
(0.57)\end{array}$ \\
\hline Observations & 993 & 993 \\
\hline Prob $>\chi^{2}$ & 0 & 0 \\
\hline Pseudo $R^{2}$ & 0.1686 & 0.2644 \\
\hline
\end{tabular}

Notes: estimates are marginal effects. Absolute value of $z$ statistics in parentheses. ${ }^{* * *} p<0.01,{ }^{* *} p<0.05,{ }^{*} p<0.1$. Data source: authors' survey. 
ern irrigation technology with greater extent (Table 5), and with greater intensity in the case of household-based technology (Table 6). If a subsidy policy is applied, the probability of adopting modern irrigation technology will increase by $11.7 \%$ for household-based irrigation technology and by $2 \%$ for community-based irrigation technology. Similarly, the probability of an increase in crop sown areas using household-based irrigation technology is $10.6 \%$.

Similarly, in both Logit and Tobit regressions, the coefficient of the extension service activities variable is positive and statistically significant for household-based irrigation technology. This result suggests that when extension service activities are accessible to farmers, the probability that farmers adopt household-based irrigation technology significantly increases. If extension service activities are available, the possibility of adopting household-based irrigation technology increases by $10.6 \%$, and the probability of increase in crop sown areas is $10.2 \%$.

Having a stronger economic incentive significantly facilitated farmers adopting household-based irrigation technology, but hindered the adoption of community-based technology. The estimated coefficient of the IFCI is positive and statistically significant in the model of household-based irrigation technology (Table 5, column 1). It implies that when farmers need to pay higher irrigation fees in relation to their limited net cropping income, they are more concerned about the adoption of household-based irrigation technology, which is expected to reduce the application of irrigation and relevant production inputs for irrigation. However, an interesting finding is that the coefficient of IFCI in the model of community-based irrigation technology (column 2) is negative and also significant. This result indicates that having a higher irrigation fee ratio will hinder the adoption of community-based irrigation technology. Finally, our results also have not indicated the significant role of economic incentives in increasing adoption intensity of irrigation technology (Table 6).

\section{Discussion and conclusions}

In this paper, we have sought to explore the importance of governmental support measures and economic incentives for the adoption of modern irrigation technology in China. Descriptive statistical analyses show that household-based irrigation technology has become noticeable in almost every Chinese village. In contrast, only about half of Chinese villages have adopted community-based irrigation technology. Adoption levels are lower at the household and plot scales. Amongst those households adopting modern irrigation technology, there are very few adopters that use it in all their crop sown areas; this observation especially applies to community-based irrigation technology.

Overall, our descriptive and econometric analyses reveal that governmental support has played an important role in promoting the adoption of modern irrigation technology. Descriptive statistical analyses show positive differences in adoption levels of modern irrigation technology when subsidies are available (Table 3). Moreover, econometric results demonstrate that the availability of subsidies has a positive and significant impact on adoption extent of both described types of modern irrigation technology (Table 5), and on adoption intensity of household-based technology (Table 6). These results are consistent with results from previous research (Bjornlund et al., 2009; Dinar and Yaron, 1992; Feder and Umali, 1993) and confirm the relevance of subsidies in encouraging adoption of agricultural innovations. In fact, subsidies appear as the most influential and comprehensive policy for encouraging the adoption of household-based and community-based irrigation technology. However, only $10 \%$ of villages are currently eligible for such support. Consideration should be given to extend the subsidy to include more farmers in the future. Since these subsidies are a public expenditure which also provides private benefits, they should be made available until the advantages of the technology are known to farmers and they adopt the technology by themselves.

Subsidies to motivate adoption should be combined with actions to promote knowledge of the benefits of advanced irrigation technologies amongst farmers. Statistical analyses show positive differences in adoption levels of householdbased irrigation technology when extension service activities are accessible to farmers. This is corroborated by the econometric results, showing that the probability that farmers adopt household-based irrigation technology significantly increases when extension service activities are accessible to them. This is in agreement with previous findings in literature (Dong, 2008; Feder and Umali, 1993; Ommani et al., 2009). Conversely, the descriptive statistical analyses for the levels of adoption intensity of community-based irrigation technology do not show differences when extension service activities are accessible to farmers (Table 3). Similarly, the econometric results show that there is no impact of extension service activities on the adoption of community-based irrigation technology. This lack of impact might be because the decision to adopt community-based technology is highly influenced by local leaders - village, township and even county leaders. Nevertheless, the provision of extension services makes a valuable contribution by spreading information about the beneficial aspects of the technology. Consideration should be given to expanding extension efforts for these technologies in areas which have a high potential benefit but currently low adoption because of limited awareness or knowledge. Overall, it seems clear that there is scope to strengthen the extent and integration of targeted subsidies and extension support for irrigation technology where there is most potential benefit.

Compared with governmental support, the present irrigation pricing policy has played a very important role in promoting the adoption of household-based irrigation technol- 
ogy. Descriptive statistical analyses show higher levels of adoption of modern irrigation technology when irrigation charges are levied and IFCI is greater than 0 , but these differences are large only for adoption extent of household-based irrigation technology. Our econometric results confirm that the payment for water and the adoption level of householdbased irrigation technology are positively and significantly related. Our result implies adoption of household-based irrigation technology is influenced by irrigation price policy. Irrigation pricing can play an important role in inducing farmers to change their irrigation behavior. This result is consistent with previous studies from Caswell et al. (1990) and Dinar and Yaron (1992).

Interestingly, the impact of irrigation pricing on the extent of adoption of community-based irrigation technology shows significant and negative values. An explanation for this is that there is some substitution effect between household- and community-based irrigation technology. If farmers have higher incentives to adopt household-based irrigation technology, there may be fewer incentives to invest in community-based irrigation technology, which has an added barrier for adoption due to high costs. In fact, such a relationship further indicates the significant role of irrigation pricing policy in promoting the adoption of modern irrigation technology. Compared with community-based irrigation technology, household-based irrigation technology is cheaper and easier to adopt by small and individual farmers, which is more consistent with the present production environment in China. Therefore, instead of investing in expensive community-based irrigation technology, the government should consider putting more effort into encouraging farmers to adopt household-based irrigation technology through appropriate and targeted irrigation pricing and extension policies.

Within the limits of available data, the econometric models used here have been applied to groups of irrigation technologies together rather than to individual irrigation technologies in detail. The limitations could be overcome with further work through collecting more data for the individual technology, and combining both quantitative and qualitative methods. If possible, we could conduct follow-up surveys to create panel data with multiple time points to further improve econometric estimates. In addition, although policies and incentive mechanisms can play a role in promoting the adoption of modern irrigation technology, the significance of their role may differ according to farmers' characteristics, such as their different degrees of wealth. Such interesting issues can also be explored further in future studies.

Acknowledgements. The authors thank Lijuan Zhang, Yumin Li, Yake Liu and Chen Huang for their support in survey translation and data cleaning; Ian Holman, David Zilberman, Ai Xiaoqing, Richard Hardiman, Christopher J. Perry and Wilko Schweers for their comments; Maarten Buis, Nick Cox and Tirthankar Chakravarty for their econometric suggestions;
Xiong Wei for the remote sensing data; and Marie Paul Benassi, Simon Spooner, Paul van Meel and Lars Skov Andersen from the European Union delegation in Beijing for their interesting background comments. The authors gratefully acknowledge comments from Christopher Martius, Mariya Aleksandrova and an anonymous referee. We acknowledge financial support from the Max Planck Institute for Meteorology, the Kompetenzzentrum Nachhaltige Universität of Hamburg University, the PROMOE program of the Universitat Politècnica de València, the National Natural Sciences Foundation of China (71161140351), the Chinese Ministry of Science and Technology (2012CB955700), and the Institute of Geographical Sciences and Natural Resources Research (IGSNRR), Chinese Academy of Sciences (2012ZD2008).

Edited by: A. Turner

\section{References}

Belder, P.: Effect of water-saving irrigation on rice yield and water use in typical lowland conditions in Asia, Agr. Water Manage., 65, 193-210, 2004.

Bjornlund, H., Nicol, L., and Klein, K. K.: The adoption of improved irrigation technology and management practices-A study of two irrigation districts in Alberta, Canada, Agr. Water Manage., 96, 121-131, 2009.

Blanke, A., Rozelle, S., Lohmar, B., Wang, J., and Huang, J.: Water saving technology and saving water in China, Agr. Water Manage., 87, 139-150, 2007.

Castilla, N.: Drip irrigation management and water saving in protected culture, in: Protected cultivation in the Mediterranean region CIHEAM/IAV Hassan II, edited by: Choukr-Allah, R., Paris, 189-202, 1999.

Caswell, M., Lichtenberg, E., and Zilberman, D.: The effects of pricing policies on water conservation and drainage, Am. J. Agron. Econ., 72, 883-890, 1990.

Cheng, H. and Hu, Y.: Economic transformation, technological innovation, and policy and institutional reforms hold keys to relieving China 's water shortages, Environ. Sci. Technol., 45, 360361, 2011.

Cheng, H., Hu, Y., and Zhao, J.: Meeting China's water shortage crisis: Current practices and challenges, Environ. Sci. Technol., 43, 240-244, 2009.

CPC: Communist Party of China, Central Committee; State Council of China, Number 1 document for 2011, Decision from the CPC Central Committee and the State Council on accelerating water conservancy reform and development, from: http://www. gov.cn/gongbao/content/2011/content1803158.htm (last access: 5 August 2011), 2010.

CPC: Communist Party of China. Chinese Central Government's official web portal, 12th five-years Plan, from: http://www.gov. cn/2011lh/content_1825838.htm (last access: 3 August 2011), 2011a.

CPC: Communist Party of China. Chinese Central Government's official web portal, China's spending on water conservation doubles during 11th five-year Plan, from: http://english.gov.cn/ 2011-01/31/content1796940.htm (last access: 3 August 2011), 2011b.

Dinar, A. and Yaron, D.: Adoption and abandonment of irrigation technology, Agr. Econ., 6, 315-332, 1992. 
Dong, B.: Food and agriculture organization of the united nations. Study on environmental implication of water saving irrigation in Zhanghe irrigation system, from: http://www.fao.org/nr/water/ espim/.../Study_environmentwatersaving.pdf (last access: 1 August 2011), 2008.

Erenstein, O., Farooq, U., Malik, R. K., and Sharif, M.: On-farm impacts of zero tillage wheat in south Asia's rice-wheat systems, Field Crops Res., 105, 240-252, 2008.

FAO: Food and Agriculture Organization of the United Nations. Global information and early warning system on food and agriculture (GIEWS), A severe winter drought in the north China plain may put wheat production at risk, from: http://www.fao. org/docrep/013/al975e/al975e00.pdf, last access: 6 August 2011.

Feder, G. and Umali, D. L.: The adoption of agricultural innovations: A review, Technol. Forecast. Social Change, 43, 215-239, 1993.

Finlayson, B., Barnett, J., Webber, M., and Wang, M.: Pricing China's irrigation water, Global Environ. Change, 18, 617-625, 2008.

Huang, Q., Rozelle, S., Howitt, R., Wang, J., and Huang, J.: Irrigation water demand and implications for water pricing policy in rural China, Environ. Develop. Econ., 15, 293-319, 2010.

Liu, Y., Huang, J., Wang, J., and Rozelle, S.: Determinants of agricultural water saving technology adoption: An empirical study of 10 provinces of China, Ecol. Econ., 4, 462-472, 2008.

Mei, C. and Dregne, H. E.: Review article: Silt and the future development of China's yellow river, Geograph. J., 167, 7-22, 2001.

MWR - Ministry of water resources in China: Water Resources Bulletin 2013, China Water Power Press, Beijing, 2013.

Negri, D. H. and Brooks, D. H.: Determinants of irrigation technology choice, from: http://ageconsearch.umn.edu/bitstream/32069/ 1/15020213.pdf (last access: 15 June 2011), 1990.

NBSC - National Bureau of Statistics of China: China Statistical Yearbook 2009, Beijing, China, 2010.

Ommani, A. R., Chizari, M., Salmanzadeh, C., and Hosaini, J. F. A.: Predicting adoption behavior of farmers regarding on-farm sustainable water resources management (SWRM): Comparison of models, J. Sustain. Agr., 33, 595-616, 2009.

Qiu, J. J., Tang, H. J., Frolking, S., Boles, S., Li, C., Xiao, X., Liu, J., Zhuang, Y. H., and Qin, X. G.: Mapping single-, double, and triple-crop agriculture in China at $0.5 \times 0.5^{\circ}$ by combining county-scale census data with a remote sensing-derived land cover map, from: http://www.geocarto.com.hk/cgi-bin/pages1/ june03/3_qiu.pdf (last access: 28 July 2011), 2003.

Tiwari, D. and Dinar, A.: Role and use of economic incentives in irrigated agriculture, from: http://go.worldbank.org/ 4AFBYCEBW0 (last access: 27 December 2011), 2000

Train, K.: Qualitative choice analysis: Theory, econometrics, and an application to automobile demand, from: http://elsa.berkeley. edu/books/choice.html (last access: 15 July 2011), 1993.

USDA: Communist Party of China, Central Committee; State Council of China, Number 1 document for 2011, Decision from the CPC Central Committee and the State Council on accelerating water conservancy reform and development, Unofficial translation, from: http://gain.fas.usda.gov/Recent_ GAIN_Publications/Agricultural_Policy_Directive_Beijing China_-_Peoples_Republic_20of5-4-2011.pdf (last access: 3 August 2011), 2011a.
USDA: People's Republic of China, 12th five-year Plan (agricultural section), Unofficial translation, from http://gain.fas.usda.gov/Recent_GAIN_Publications/China\% 27s_12th_Five-Year_Plan_(Agricultural_Section)_Beijing China_-_Peoples_Republic_of5-3-2011.pdf, (last access: 3 August 2011), 2011b.

Wang, J., Xu, Z., Huang, J., and Rozelle, S.: Incentives in water management reform: Assessing the effect on water use, production, and poverty in the yellow river basin, Environ. Develop. Econ., 10, 769-799, 2005.

Webb, R. S., Frasier, W. M., Schuck, E. C., Umberger, W. J., and Ellingson, L. J.: Adoption of more technically efficient irrigation systems as a drought response, Int. J. Water Resour. Develop., 21, 651-662, 2005.

Wu, Z. Y., Lu, G. H., Wen, L., and Lin, C. A.: Reconstructing and analyzing China's fifty-nine year (1951-2009) drought history using hydrological model simulation, Hydrol. Earth Syst. Sci., 15, 2881-2894, doi:10.5194/hess-15-2881-2011, 2011.

Wu, P. and Zhao, X.: Impact of climate change on agricultural water use and grain production in China, NongyeGongchengXuebao/Transactions of the Chinese Society of Agricultural Engineering, 26, 1-6, 2010.

Xinhua: Xinhua news agency. Water-saving irrigation techniques to boost crops, from: http://www.globaltimes.cn/NEWS/tabid/99/ ID/695165/Water-saving-irrigation-techniques-to-boost-crops. aspx, last access: 20 March 2012.

Xiong, W., Holman, I., Lin, E., Conway, D., Jiang, J., Xu, Y., and Li, Y.: Climate change, water availability and future cereal production in China, Agr. Ecosyst. Environ., 135, 58-69, 2010.

Yang, H., Zhang, X. J., and Zehnder, A. J. B.: Water scarcity, pricing mechanism and institutional reform in northern China irrigated agriculture, Agr. Water Manage., 61, 143-161, 2003.

Zhang, H., Turner, N. C., Deng, X., and Shan, L.: Improving agricultural water use efficiency in arid and semiarid areas of China, Agr. Water Manage., 80, 23-40, 2005.

Zhao, X., Jin, J., and Wu, P.: Impact of climate change and irrigation technology advancement on agricultural water use in China, Climatic Change, 100, 797-805, 2010.

Zhou, S., Herzfeld, T., Glauben, T., Zhang, Y., and Hu, B.: Factors affecting Chinese farmers' decisions to adopt irrigation technology, Can. J. Agr. Econ., 56, 51-61, 2008.

Zilberman, D. and Caswell, M.: The choices of irrigation technology in California, Am. J. Agr. Econ., 67, 224-234, 1985.

Zou, X., Li, Y., Li, K., Cremades, R., Gao, Q., Wan, Y., and Qin, X.: Greenhouse gas emissions from agricultural irrigation in China, Mitig. Adapt. Strat. Global Change, 135, 1-21, 2013a.

Zou, X., Li, Y., Cremades, R., Gao, Q., Wan, Y., and Qin, X.: Cost-effectiveness analysis of water-saving irrigation technologies based on climate change response: A case study of China, Agr. Water Manage., 129, 9-20, 2013b. 